\title{
KETENTUAN WARIS DAN PROBLEMATIKANYA PADA MASYARAKAT MUSLIM INDONESIA
}

\author{
Syahrul Mubarak Subeitan \\ Fakultas Syariah, Institut Agama Islam Negeri Manado, Indonesia \\ Email: syahrul.subeitan@iain-manado.ac.id
}

\begin{abstract}
ABSTRAK
Perkara waris telah diatur dalam ketentuan di Indonesia, yaitu hukum adat, hukum Islam dan hukum waris perdata. Khusus muslim, juga berlaku Kompilasi Hukum Islam (KHI). Meskipun demikian, masyarakat muslim di Indonesia sering timbul kecekcokan yang mungkin akan mengakibatkan hancurnya hubungan antar keluarga. Hal ini sebenarnya tidak perlu terjadi seandainya semua memahami apa yang seharusnya dilakukan, apa yang menjadi haknya dan apa saja yang menjadi kewajiban yang berkaitan dengan harta warisan tersebut. Dengan demikian, perlu adanya sebuah aturan mengenai hukum waris di setiap lapisan masyarakat, agar kedepannya masyarakat tidak mengalami kebingungan dalam memecahkan masalah tentang waris dan perselisihan antar persaudaraan mengenai waris tersebut dapat diminimalisir. Berdasarkan hal tersebut, penulis berinisiatif untuk membahas aturan kewarisan di Indonesia, serta problematikanya dengan metode kualitatif-deskriptif. Tujuan dalam tulisan ini adalah untuk mengetahui hukum kewarisan di Indonesia, serta memahami problematika yang terjadi dalam praktik pada masyarakat muslim di Indonesia. Dari ketentuan waris yang ada dan tidak bisa dipungkiri bahwa pilihan hukum pada masyarakat muslim Indonesia yang berbeda-beda, namun tetap dengan suatu tujuan untuk menggapai kemaslahatan pada setiap pihak.
\end{abstract}

Kata kunci: Ketentuan Waris; Kompilasi Hukum Islam; Maslahat. 


\section{PENDAHULUAN}

Hukum waris atau dalam hukum waris Islam disebut dengan faraid atau mawaris merupakan hukum yang mengatur peralihan harta/benda kepemilikan seorang pewaris, baik berupa uang, tanah dan lain sebagainya, yang telah meninggal dan meninggalkan ahli waris sebagai akibat dari hukum waris tersebut (As-Sabuni, 1996).

Sistem hukum di Indonesia mengenal yang namanya sistem hukum kekeluargaan, yaitu sistem dalam proses pembagian harta warisannya diselesaikan secara kekeluargaan. Berdasarkan praktik warisan di masyarakat, baik dalam satu keluarga maupun di Pengadilan, terdapat berbagai keragamaan sistem penyelesaian, seperti menggunakan hukum Islam, adat, hukum waris perdata (BW), bahkan menggabungkan satu sistem dengan sistem lainnya dalam mendapatkan nilai perdamaian agar para ahli waris tidak saling bertentangan.

Walaupun ketentuan hukum waris telah diatur secara terperinci, baik dari hukum kewarisan Islam maupun hukum kewarisan di Indonesia, berbicara mengenai masalah warisan, masyarakat di Indonesia sering timbul kecekcokan yang mungkin akan mengakibatkan hancurnya hubungan antar kekeluargaan. Dalam praktiknya dapat dilihat seperti pembagian warisan tidak dibagi sama persis dengan ketentuan waris Islam dan kewarisan di Indonesia kepada para ahli waris, karena dalam penelitian Asni menyatakan bahwa "pembagian waris dengan bagian anak perempuan lebih besar dari pada bagian anak lain dengan alasan bahwa anak laki-laki lebih bungsu/muda dibandingkan dengan anak perempuan". Selain itu, pembagian warisan yang dilakukan oleh orang tua sebelum mereka meninggal juga kerap kali dapat ditemukan pada masyarakat plural Indonesia (Zubair, 2014).

Fenomena demikian memang berbeda dengan ketentuan waris Islam, karena waktu pembagian warisan bukan akibat kematian, melainkan adanya kekhawatiran orang tua kepada ahli warisnya nanti kelak terjadi kecekcocakan masing-masing pihak setelah orang tua tersebut meninggal dunia. Seharusnya waris merupakan harta pewaris setelah pewaris meninggal dunia baru dapat dibagikan kepada masing-masing ahli waris, tidak bisa dikatakan waris jika si pewaris masih hidup (Syarifuddin, 2005).

Hal ini sebenarnya tidak perlu terjadi seandainya semua memahami apa yang seharusnya dilakukan, apa yang menjadi hak-haknya dan apa saja yang menjadi kewajiban-kewajibannya yang berkaitan dengan harta warisan tersebut. Karena ketidaktahuan dan ketidakpahaman, banyak faktor yang menjadi penyebab atau sumber konflik dalam masalah kewarisan ini. Dengan demikian, perlu adanya 
sebuah aturan mengenai hukum waris di setiap lapisan masyarakat, agar kedepannya masyarakat tidak mengalami kebingungan dalam memecahkan masalah tentang waris dan perselisihan antar persaudaraan mengenai waris tersebut dapat diminimalisir. Berdasarkan hal tersebut, penulis berinisiatif untuk membahas aturan kewarisan di Indonesia, serta problematikanya. Tujuan dalam tulisan ini adalah untuk mengetahui hukum kewarisan di Indonesia, serta memahami problematika yang terjadi dalam praktik pada masyarakat muslim di Indonesia.

\section{METODE PENELITIAN}

Penelitian ini berfokus pada ketentuan-ketentuan hukum waris yang berlaku di Indonesia dengan melihat probematika pada masyarakat muslim Indonesia. Adapun Jenis pendekatan penelitian yang digunakan dalam penelitian ini adalah kualitatif-deskriptif, yaitu penelitian ini digunakan untuk melihat suatu fenomena dan problematika sosial yang terjadi pada masyarakat muslim Indonesia. Data atau informasi didapatkan dari berbagai literatur yang terkait.

\section{HASIL DAN PEMBAHASAN}

\section{Ketentuan Waris Islam}

Ketentuan waris Islam, khususnya aturan waris Islam klasik berasal dari struktur dasar yang telah ditetapkan dalam produk hukum Islam, yaitu Al-Qur'an, Hadis maupun Ijtihad para Ulama yang telah diuraikan dan disistematisasi oleh imam-imam madzhab melalui berbagai metode dan interpretasi. Adapun ketentuan waris dalam Islam tidak luput dari 3 (tiga) rukun yang harus ada, yaitu: Pertama, pewaris, atau bisa juga disebut sebagai orang yang mewariskan, yaitu seseorang yang telah meninggal dunia dan meninggalkan harta warisan kepada ahli warisnya (Syarifuddin, 2005). Mengenai pewaris, dalam QS. An-Nisa [4]: 7 disebutkan bahwa: "Bagi orang laki-laki ada hak bagian dari harta peninggalan ibu-bapa dan kerabatnya, dan bagi orang wanita ada hak bagian (pula) dari harta peninggalan ibu-bapa dan kerabatnya, baik sedikit atau banyak menurut bahagian yang telah ditetapkan."

Ayat di atas dapat menunjukkan bahwa pewaris merupakan di antara orang tua ataupun kerabat yang telah meninggal dunia. Selain dari ayat tersebut, QS. An-Nisa [4] ayat 11, 12 dan 176 berbicara juga mengenai pewaris yang lebih dirincikan lagi, seperti pada ayat 11 bahwa pewaris bukan hanya orang tua baik bapak dan ibu, serta anak, melainkan cucu, kakek dan nenek, sedangkan ayat 12 dan 176 mengenai pewaris dari kerabat dirincikan bahwa suami menjadi pewaris 
bagi istrinya, begitu juga sebaliknya, serta saudara laki-laki atau perempuan menjadi pewaris bagi saudara lainnya (Syarifuddin, 2005).

Kedua, ahli waris, merupakan seseorang yang berhak menerima harta warisan dari si pewaris, karena ada sebab yang bisa mewarisi, baik yang sebabkan dengan hubungan nasab/keturunan/darah, perkawinan, serta memerdekakan budak. Dalam Islam terdapat 15 ahli waris dari golongan laki-laki, yaitu mulai dari anak laki-laki, bapak, suami, sampai dengan al-mu'tiq atau seorang laki-laki yang memerdekakan budak, sedangkan terdapat 10 ahli waris dari golongan perempuan, yaitu mulai dari anak perempuan, ibu, istri, hingga al-mu'tiqah atau seorang perempuan yang memerdekakan budak. Masing-masing dari golongan tersebut memiliki bagian yang telah ditentukan dalam ketentuan waris Islam (Salim, 2005).

Ketiga, harta warisan, merupakan segala sesuatu dari harta benda yang telah ditinggalkan oleh pewaris untuk dialihkan kepada ahli waris. Harta waris yang dimaksud tidak secara keseluruhan dialihkan kepada ahli waris, setelah semua hak si pewaris telah ditunaikan terlebih dahulu, seperti mengurus segala keperluan dalam pengurusan jenazah si pewaris, melunasi segala hutang yang pernah dilakukan oleh si pewaris, serta memenuhi wasiat yang telah dibuat sebelum pewaris meninggal dunia. Dari semua ketentuan harta warisan ini adalah dengan mendahulukan hak orang lain dari harta si pewaris, sebelum dibagikan kepada ahli waris (Syarifuddin, 2005).

Hukum waris Islam memang menjadi salah satu aspek hukum yang lama bertahan dibandingkan dari aspek hukum lain, seperti hukum bisnis maupun hukum pidana yang selalu berubah-ubah. Selain dari bentuk kesakralan mengenai faraid di kalangan umat Islam, penyebab lainnya adalah ketentuan waris Islam sudah sangat rinci dijelaskan di dalam Al-Qur'an dan Hadis yang kerap kali tidak dapat ditemukan suatu interpretasi, karena karakter hukum waris sendiri sangat kuat (Wahib, 2014). Meskipun demikian, Indonesia sendiri sudah cukup progresif melakukan suatu interpretasi dalam ketentuan waris ini, sepert ketentuan ahli waris pengganti maupun ketentuan wasiat wajibah yang merupakan bentuk reformasi dalam perkembangan ketentuan waris saat ini.

\section{Ketentuan Waris di Indonesia}

Pembacaan ketentuan waris di Indonesia hampir sama dengan ketentuan waris pada Islam yang tidak lepas dari 3 (tiga) unsur pokok yang harus ada, yaitu: Pertama, pewaris, yaitu peninggal warisan atau disebut pewaris adalah orang yang meninggal dunia dan meninggalkan harta benda kepada orang lain; Kedua, ahli waris, yaitu orang yang menggantikan pewaris di dalam kedudukannya 
terhadap warisan, baik untuk seluruhnya maupun untuk sebagian tertentu, dan; Ketiga adalah harta warisan, yaitu segala harta kekayaan yang ditinggalkan oleh orang yang meninggal dunia yang berupa semua harta kekayaan dari yang meninggal dunia setelah dikurangi dengan semua utangnya. Ketiga unsur tersebut harus dipenuhi dalam hal terjadi pewarisan, jika salah satu atau lebih unsur tersebut tidak ada, maka proses pewarisan tidak terjadi.

Di Indonesia, khususnya dalam masalah waris, memiliki 3 sistem hukum, yaitu: hukum adat, hukum Islam dan hukum perdata (BW). Dalam hukum adat, ada tiga sistem warisan, yaitu individu, kolektif dan mayorat (Hazairin, 1982).

\section{Sistem Pewarisan Individu}

Sistem pewarisan individu merupakan suatu pendistribusi warisan berdasarkan individu atau pewaris pribadi untuk dimiliki secara individual. Setiap ahli waris bebas menggunakan atau mentransfer warisan yang diperoleh kepada pihak lain. Sistem ini dapat ditemukan pada masyarakat bilateral, seperti mencar dan mentas di Jawa, dan masyarakat patrilineal, seperti manjae di Batak atau peminggir di Lampung. Dalam masyarakat matrilineal, seperti penduduk asli Minangkabau, ada perubahan sistem pewarisan menjadi sistem pewarisan individu. Hal ini disebabkan para ahli waris tidak lagi terikat pada satu rumah keluarga (rumah gadang) atau rumah orang tua dan memiliki pekerjaan di daerah yang luas. Karena itu, mereka tidak lagi berkeinginan untuk memiliki warisan bersama.

\section{Sistem Warisan Kolektif}

Sistem warisan kolektif merupakan suatu pendistribusi warisan dengan mentransfer warisan tak terpisahkan kepada ahli waris. Setiap ahli waris memiliki hak untuk mengelola, menggunakan, atau menerima hasil warisan kolektif. Dalam masyarakat adat Minangkabau sebagai matrikal masyarakat Sumatera Barat, mamak kepala waris memimpin pengelolaan tanah pusako secara bersama-sama dilakukan oleh ahli waris yang hanya menggunakan atau menggerebek bauntuik. Di pribumi Ambon atau Maluku, tanah dati digunakan oleh ahli waris dalam mengendalikan kepala dati. Dalam masyarakat adat Minahasa di Sulawesi Utara sebagai sistem patrilineal, mereka memiliki kalakeran, yaitu tanah keluarga yang tidak boleh dibagi dan dibagikan kepada ahli waris tetapi harus digunakan oleh ahli waris yang di bawah dan dikelola oleh orang kendalitua untaranak, haka umbana, atau paki itenan tanah-tanah. Masyarakat patrilineal lainnya, seperti penduduk asli Lampung, mereka memiliki tanah menyanak atau tanah repong yang seharusnya tidak didistribusikan kepada ahli waris tetapi dikelola bersama. Sistem warisan kolektif berubah ke sistem pewarisan individu karena penggunaan 
warisan adalah individu dan peran pemimpin masyarakat dalam manajemen warisan lemah.

\section{Sistem Warisan Mayorat}

Sistem warisan mayorat adalah pemindahan hak untuk menempati warisan yang terpisahkan kepada anak tertua yang dianggap sebagai penerus tanggung jawab keluarga setelah orang tuanya meninggal. Anak sulung mengelola warisan untuk hidup dan mengambil alih saudara-saudaranya yang belum dewasa sampai mereka dewasa dan mandiri. Ada dua jenis sistem warisan mayorat, yaitu mayorat laki-laki dan mayorat perempuan. Mayorat laki-laki mentransfer pengelolaan warisan kepada putra tertua. Hal ini dibahasakan oleh penduduk asli Lampung dengan beradat pepadun, yaitu anak punyimbang atau putra sulung dari istri pertama memimpin, mengelola, dan mendominasi warisan tak terbagi. Kemudian mayorat perempuan mentransfer pengelolaan warisan kepada putri sulung. Mayorat ini menerapkan putri tertua dalam pengelolaan pribumi Semendo di Sumatra Selatan.

Adapaun secara spesifik pembagian kekerabatan atau kekeluargaan pada masyarakat adat di Indonesia dan masing-masing memiliki sistem hukum waris tersendiri. Hal tersebut sebagaimana yang telah dituangkan dalam buku Wirjono Prodjodikoro bahwa terdapat tiga (3) bentuk sistem kekerabatan atau kekeluargaan pada masyarakat adat Indonesia, yaitu: Pertama, golongan patriachaat atau patrilineal atau kebapakan di mana golongan kekerabatan tersebut dapat ditemukan pada masyarakat Bali, Ambon, Batak, Alas dan Tanah Gayo; Kedua, golongan matriaachaat atau matrilineal atau keibuan di mana golongan kekerabatan tersebut dapat ditemukan pada masyarakat Minangkabau, dan Ketiga, golongan parental atau bilateral atau kebapak-ibuan di mana golongan kekerabatan tersebut dapat ditemukan pada masyarakat Lombok, Kalimantan, Sulawesi, Jawa dan Madura (Prodjodikoro, 1983). Golongan ketiga ini merupakan mayoritas atau terbanyak penganut masyarakat Indonesia. Dari ketiga golongan di atas juga berpengaruh pada sistem pembagian warisan di mana golongan patrilineal yang lebih berhak menerima warisan adalah dari kerabat laki-laki saja, karena perempuan bukan termasuk ahli waris, sedangkan golongan matrilineal sebaliknya, yaitu perempuanlah yang berhak menerima warisan, bukan laki-laki. Adapun golongan parental, baik laki-laki dan perempuan, masing-masing memperoleh harta warisan sesuai dengan ketentuan yang berlaku pada adatistiadatnya.

Selain hukum adat di atas, terdapat hukum Islam yang juga digunakan dalam sistem kewarisan di Indonesia. Pada umumnya, terdapat tiga sistem hukum waris Islam di Indonesia, yaitu, sistem hukum waris Syafi'i (patrilineal), sistem 
hukum waris Hazairin (bilateral) dan Kompilasi Hukum Indonesia (KHI). Setelah itu, ada pemikiran datang dari Munawir Sadzali yang mengemukakan sebuah kritikan porsi yang diterima oleh laki-laki dan perempuan. Munawir mengemukakan pendapat bahwa antara laki-laki dan perempuan mendapat porsi yang sama, yaitu satu banding satu, dengan gagasan reaktualisasi hukum Islam bahwa menurutnya hukum Islam itu tidak sepenuhnya ta'abbudi, melainkan mengandung sifat ta'aqquli, sehingga hukum Islam bersifat lentur yang siap akan perkembangan zaman yang semakin modern (Rofiq, 2012).

Beberapa ketentuan sistem warisan di atas, tak jarang didapati suatu ketentuan mengenai kewarisan berbeda satu sama lain. Misalnya, Syafi'i dan Hazairin memiliki interpretasi yang berbeda dalam praktik mengenai kalalah. Istilah kalalah disebutkan pada surah An-Nisa ayat 176. Hal itu mempengaruhi pembagian saudara kandung sebagaimana disebutkan dalam surah An-Nisa ayat 12 dan 176. Menurut Hazairin, kalalah adalah orang yang meninggal tidak ada putra-putri dan keturunan mereka laki-laki-perempuan. Dalam posisi ini, saudara laki-laki atau perempuan adalah pewaris almarhum. Pembagian saudara laki-laki atau saudara perempuan ditentukan pada surat An-Nisa ayat 12 jika ayah selamat. Jika ayah meninggal sebelum almarhum, saudara laki-laki atau saudara perempuan ditentukan pada surah An-Nisa ayat 176. Hazairin tidak membedakan saudara kandung, wanita dewasa dan seterusnya yang memiliki pembagian yang sama. Sedangkan Syafi'i mendefinisikan kalalah adalah almarhum tidak meninggalkan laki-laki, anak dari laki-laki dan ayah. Dalam kondisi ini, almarhum adalah kalalah, saudara kandung akan berhak atas dirinya sendiri. Surah An-Nisa ayat 12 digunakan sebagaimana mestinya, sedangkan surah An-Nisa ayat 176 digunakan untuk saudara kandung dan kerabat (Barlinti, 2013).

Dua perspektif di atas, KHI menggabungkan pendapat Syafi'i dan Hazairin. Berdasarkan ketentuan KHI, kalalah adalah almarhum tidak meninggalkan anak laki-laki maupun perempuan, anak dari anak laki-laki maupun perempuan dan ayah. Dalam hal ini, Pasal 181 KHI menetapkan bahwa pembagian warisan sama dengan surat An-Nisa ayat 12 dan Pasal $182 \mathrm{KHI}$ menentukan pembagian saudara kandung dan kerabat sama seperti surat An-Nisa ayat 176 (Barlinti, 2013).

Selain ketentuan hukum waris adat dan Islam di atas, terdapat beberapa ketentuan dalam Hukum Perdata (BW) tentang kewarisan. Adapun hukum waris merupakan salah satu undang-undang yang ditulis dalam KUHPerdata dalam Buku II. Menurut Surini Ahlan Sjarif dan Nurul Elmiyah, alasan penempatan hukum waris dalam Buku II KUHPerdata adalah (1) Hak untuk mewarisi diidentifikasi sebagai hak milik yang diberikan pada Pasal 528 KUHPerdata. (2) 
Hak untuk mewarisi adalah salah satu cara untuk mendapatkan hak milik, sebagaimana didefinisikan pada Pasal 584 KUHPerdata (Sjarif \& Elmiyah, 2010).

KUHPerdata membagi ahli waris menjadi dua jenis, yaitu pewaris ab intestato dan ahli waris testamentair. Ahli waris dari intestato adalah ahli waris karena hubungan perkawinan dan kekerabatan. Ahli waris testamentair adalah ahli waris yang ditunjuk dalam wasiat atau surat wasiat. Ada klasifikasi ahli waris ab intestato. Arti klasifikasi Kode Sipil berbeda dari klasifikasi ahli waris dalam hukum waris Islam. Klasifikasi KUHPerdata memiliki arti yang sama dengan kelompok primer Hazairin, yang kelompok-kelompoknya berhak mewarisi dalam urutan. Klasifikasi ahli waris yang diatur dalam KUHPerdata adalah (1) Anak atau keturunan dan istri atau suami (Pasal 852). (2) Orang tua (ayah dan ibu) dan saudara kandung (Pasal 854-859). (3) Kakek dan nenek atau nenek moyang lainnya dengan garis lurus ke atas (Pasal 853). (4) Kerabat garis samping sampai tingkat keenam (Pasal 861).

\section{Problematika Waris di Indonesia}

Penyelesaian sengketa kewarisan di Indonesia secara prosedur diserahkan

ke Pengadilan Negeri maupun Pengadilan Agama. Pengadilan Agama menggunakan hukum Islam dan legislasi terkait untuk menyelesaikan perselisihan. Sementara sengketa warisan di Pengadilan Negeri diselesaikan oleh hukum adat atau hukum barat. Dalam aturan penyelesaian waris di Pengadilan Agama, terdapat aturan UU No. 7 Tahun 1989 tentang Peradilan Agama jo. UU No. 3 Tahun 2006 jo. UU No. 50 Tahun 2009 bahwa Pengadilan Agama berwenang untuk menyelesaikan sengketa warisan jika agama almarhum adalah Islam.

Ketentuan aturan di atas mengenai kewenangan Pengadilan dalam memutuskan sengketa kewarisan, terdapat beberapa kasus di Indonesia yang masih kerap terjadi sebuah ambiguitas dalam menentuan suatu aturan yang kerap didapati dalam problimatika di masyarakat. Hal ini sebagaimana dalam sebuah penelitian Sri Wahyuni yang juga mengamati pada penelitian terdahulu bahwa masyarakat kebanyakan memilih hukum adat daerah masing-masing dibandingkan dengan hukum Islam dalam menyelesaikan perselisihan kewarisan, khususnya berkaitan dengan persoalan pembagian warisan. Dalam penelitian tersebut dapat dilihat dengan sebuah contoh pada masyarakat Minang, yang bisa dikatakan bahwa masyarakat Minang sangat kental dengan ajaran agamanya, pun masih mempedomani sistem pembagian secara adat yang bercorak sistem matrilineal. Selain masyarakat Minang, terdapat juga masyarakat suku Sasak Sade, Lombok Tengah, yang juga menerapkan hal yang sama seperti masyakat Minang, yaitu 
tetap mempedomani ketentuan sistem kewarisan adat pada masyarakatnya (Wahyuni, 2016).

Selain melihat kedua contoh penerapan ketentuan waris pada masyarakat Indonesia di atas, penelitian dari Ama' Khisbul Maulana mengenai masyarakat Samin, yaitu masyarakat yang mayoritas terdapat di daerah Blora dan tersebut di daerah Jawa lainnya, khususnya Jawa Timur, menyatakan bahwa masyarakat tersebut tetap kokoh dalam mempedomani ajaran-ajaran adat mereka. Dalam penelitian Ama' yang memfokuskan untuk meneliti masyarakat Samin di Dusun Jepang Margomulyo, Bojonegoro mengenai sistem pembagian waris tetap berpedoman pada ajaran adatnya. Hal tersebut dikarenakan saking dominannya nilai-nilai adat terhadap kehidupan masyarakat Samin. Hal ini juga mengakibatkan ajaran waris Islam tidak diaplikasikan pada masyarakat Samin (Maulana, 2020).

Selain problematika mengenai pemberlakuan hukum adat dan Islam di atas, terdapat kasus di Pengadilan mengenai kewarisan antara seorang suami dan seorang istri yang telah disamarkan dengan inisial ZAN (suami) dan HBS (istri). Dalam sebuah alur kasus bahwa mereka memiliki dua putra (meninggal ketika masih anak-anak) dan dua anak perempuan, dengan inisial nama ZBN dan SBN. SBN menikahi seorang lelaki dengan inisial JM dan memiliki sembilan putra, yaitu dengan inisial HM, TM (almarhum), KM (almarhum), PM, BM, URM, OM, RM (almarhum) dan SM. Kemudian, ZAN dan istri keduanya, dengan inisial TBS, memiliki seorang putra, yaitu dengan insial AJN. Kemudian AJN menikahi seorang wanita dengan inisial NBS.

Dalam pernikahan ZAN dan HBS, HBS membawa harta warisannya dalam pernikahannya. Itu adalah sebidang tanah sebagai hadiah dari saudara lakilakinya (kakak), dengan inisial BS, yang terletak di Nagari Bandar Dolok, Simalungun. Mereka merawat tanah tersebut secara bersama-sama. Sejak HBS meninggal pada tahun 1935, tanah itu dirawat oleh suaminya, ZAN, dan anak perempuannya, yaitu ZBN dan SBN. Kemudian, kedua putri ZAN, yaitu ZBN dan SBN mengambil alih tanah tersebut mengingat ketika itu, pada tahun 1945, ayahnya meninggal dunia, yaitu ZAN. Pada tahun 1956, istri kedua ZAN, yaitu TBS mengambil alih lahan tersebut, karena anak dari ZAN, yaitu ZBN sudah meninggal dunia, sedangkan SBN menikah dengan JM. Pada tahun 2003, istri kedua ZAN, yaitu TBS, maka tanah tersebut akhirnya diambil alih oleh AJN dan istrinya, yaitu NBS (Barlinti, 2013).

Alur cerita di atas akhirnya diputuskan oleh hakim di Pengadilan Negeri Simalungun dalam sebuah putusan No. 25/Pdt.G/2008/PN.Sim yang menyatakan bahwa: 
1) Tanah tersebut merupakan warisan (estate) dari HBS;

2) Ahli waris HBS adalah HM, TM (almarhum), KM (almarhum), PM, BM, URM, OM, RM (almarhum) dan SM yang berhak atas tanah itu, dan;

3) Ahli waris memiliki hak untuk menjaga dan merawat tanah sebelum mereka mewariskan kepada ahli waris. Kemudian, putusan di atas diputuskan oleh Pengadilan Tinggi dalam putusan No. 138/Pdt/2008/PT.Mdn yang memutuskan bahwa putusan Pengadilan Negeri Simalungan tidak dapat diterima dan dicabut.

Kemudian, Hakim dari Mahkamah Agung memutuskan kasus tersebut dalam sebuah Putusan No. 3023 K/Pdt/2009 bahwa Pengadilan Negeri Simalungun dan Pengadilan Tinggi Medan telah kehilangan sebuah eksistensi hukum karena sebenarnya mereka tidak memiliki kewenangan dalam menyelesaikan kasus tersebut. Meskipun kasus ini terkait dengan sengketa kepemilikan, tetapi penggugat dan terdakwa adalah muslim. Kasus ini seharusnya diajukan ke Pengadilan Agama, sebagaimana diatur dalam "UU No. 7 Tahun 1989 jo. UU No. 3 Tahun 2006 jo. UU No. 50 Tahun 2009” (Barlinti, 2013).

Kasus di atas dapat dianalisis bahwa Kasus keluarga M melawan keluarga $\mathrm{N}$ adalah bentrokan antara hukum waris adat, barat, dan Islam. Menurut hukum adat, harta HBS milik keluarga $\mathrm{N}$, karena HBS adalah bagian dari keluarga $\mathrm{N}$ sejak menikah dengan ZAN. Selain itu, mereka tidak memiliki putra yang melanjutkan klan/keluarga. Oleh karena itu, tanah diambil alih oleh TBS (istri kedua dari ZAN). SBN tidak bisa mengurus tanah, karena bukan bagian dari keluarga N sejak pernikahannya dengan keluarga M. Hakim Pengadilan Negeri Simalungun tidak mempertimbangkan hukum adat untuk kasus ini, tetapi KUHPerdata. Mereka menganggap sumber aset itu milik HBS, bukan kelurga N. Oleh karena itu, harus didistribusikan kepada ahli waris HBS dan keluarga M, meskipun mereka adalah klan/keluarga yang berbeda dari HBS. Hakim Mahkamah Agung lebih positif untuk menyelesaikan kasus ini berdasarkan "UU No. 7 Tahun 1989 jo. UU No. 3 Tahun 2006 jo. UU No. 50 Tahun 2009”, tidak ada pilihan hukum waris untuk muslim, kecuali mengajukan kasus ke Pengadilan Agama. Oleh karena itu, mereka memutuskan bahwa putusan Pengadilan Tinggi dicabut (Barlinti, 2013).

Selain problematika di atas, tidak jarang ditemui bahwa ada sebagian masyarakat yang masih mempedomani ketentuan dalam hukum waris Islam, maupun hukum postif di Indonesia, seperti halnya dalam penelitian pembagian warisan di kalangan masyarakat muslim Banjarmasin. Dari empat puluh satu (41) kasus, ditemukan empat (4) cara dalam pembagian warisan, yaitu: Pertama, cara hibah, dengan alasan bahwa sepeninggal pewaris, anak-anak dan ahli waris lain 
tetap menjalin hubungan persaudaraan yang baik, karena orang tua tidak menginginkan kelak ada perpecahan dengan alasan harta yang telah dibagikan kepada ahli warisnya; Kedua, cara musyawarah, dengan alasan bahwa untuk menjalin kemaslahatan dan kedamaian antar keluarga karena dengan cara musyawah-mufakat dianggap lebih bijaksana dalam menentukan besaran bagian kepada ahli waris yang lebih butuh akan harta peninggalan si pewaris. Selain itu, cara ini sudah termaktud di dalam ketentuan KHI Pasal 193, dan Ketiga, cara faraidh, dengan alasan bahwa cara yang telah termaktub dalam ketentuan waris Islam merupakan pilihan terbaik yang lebih utama dibanding dengan cara lain, sebagaimana yang tertuang di dalam QS. An-Nisa ayat 11, 12 serta KHI Pasal 176. Terakhir, cara perpantangan, yaitu sebuah cara jika suami atau istri meninggal dunia, maka harta tersebut langsung dibagi dengan besaran dua banding satu (2:1) dalam ketentuan waris Islam untuk dibagikan kepada salah satu pasangan yang masih hidup. Kemudian sisa dari harta tersebut dibagikan kepada ahli waris lainnya. Sebenarnya cara ini juga sudah termaktud di dalam ketentuan KHI Pasal 96 ayat 1 yang berbunyi: “Apabila terjadi cerai mati, maka separuh harta bersama menjadi hak pasangan yang hidup lebih lama, separuh sisanya baru dibagikan dengan sistem pembagian warisan" (Rofiq, 2012).

Melihat persoalan di atas, pembagian waris dengan cara berbeda pada masyarakat Muslim Indonesia yang multikultural saat ini masih beragam, dapat dilihat secara menyeluruh dengan 3 (tiga) ketentuan dalam pembagian waris, yaitu: Pertama, pelaksanaan waris tidak berdasarkan ketentuan hukum waris; Kedua, pelaksanaan waris berdasarkan adat kewarisan masyarakat setempat, dan Ketiga, pelaksanaan waris sesuai dengan ketentuan hukum waris Islam, serta hukum positif di Indonesia. Masing-masing ketentuan tersebut punya peranannya dalam kelompok masyarakat tertentu, tentunya dengan satu tujuan, yaitu untuk mendapatkan kemaslahatan di dalamnya, seperti cara musyawarah yang mana dengan adanya musyawarah, maka akan mencapai makna keadilan dalam hukum kewarisan itu sendiri.

\section{KESIMPULAN}

Paparan di atas dapat diambil kesimpulan bahwa ketiga sistem hukum waris di Indonesia, yaitu adat, Islam dan barat, tetap berlaku dan diimplementasikan hingga saat ini. Penggunaan sistem dapat dilihat dalam sengketa warisan. Dalam masyarakat, telah berubah dari bergeser norma-norma warisan dari adat hukum ke hukum barat, atau hukum adat ke hukum Islam. Hal ini dapat dilihat dari alasan pihak-pihak yang bersengketa di pengadilan. Dalam menerapkan hukum waris, parameter peradilan hukum tidak dapat ditentukan dengan benar kecuali ditentukan oleh undang-undang yang berlaku. 
Bahkan penerapan hukum waris kontemporer yang didasarkan dengan fikih klasik, namun tetap relevan dengan problematika masyarakat muslim Indonesia. Hal tersebut didasarkan karena interpretasi masyarakat dalam membentuk suatu aturan hukum, baik dalam penerapan adat kebiasaan maupun kodifikasi dari berbagai aturan yang ada. Di satu sisi bahwa belum adanya produk hukum yang utuh dan berlaku bagi setiap lini masyarakat secara nasional yang mengatur hukum waris. Dari semua ketentuan waris yang ada dan tidak bisa dipungkiri bahwa pilihan hukum pada masyarakat muslim Indonesia yang berbeda-beda, namun tetap dengan suatu tujuan untuk menggapai kemaslahatan pada setiap pihak.

\section{REFERENSI}

As-Sabuni, M. A. (1996). Pembagian Warisan Menurut Islam. Gema Insani Press.

Barlinti, Y. S. (2013). Inheritance Legal System in Indonesia: A Legal Justice for People. Indon. L. Rev., 3, 23.

Hazairin. (1982). Hukum Kewarisan menurut Al Qur'an dan Hadis. Tintamas Indonesia.

Maulana, A. K. (2020). Pergulatan Hukum Waris Islam dan Hukum Adat: Pembagian Warisan Keluarga Muslim Masyarakat Samin. IJTIHAD, 36(2).

Prodjodikoro, W. (1983). Hukum Waris di Indonesia (2nd ed.). Sumur.

Rofiq, A. (2012). Problematika Hukum Kewarisan Islam Kontemporer di Indonesia. Puslitbang Kehidupan Keagamaan.

Salim, M. bin. (2005). Fiqh Mawaris (1st ed.). Dar Al-Fikar.

Sjarif, S. A., \& Elmiyah, N. (2010). Hukum Kewarisan Perdata Barat: Menu Pewarisan Undang-Undang. Kencana dan Badan Penerbit FHUI.

Syarifuddin, A. (2005). Hukum Kewarisan Islam (2nd ed.). Kencana.

Wahib, A. B. (2014). Reformasi Hukum Waris Di Negara-Negara Muslim. AsySyir'ah: Jurnal Ilmu Syari'ah Dan Hukum, 48(1).

Wahyuni, S. (2016). Hukum Keluarga dan Dinamika Sosial: Kajian Adat Masyarakat Samin, Maluku, Kalimantan dan Sasak. Calpulis.

Zubair, A. (2014). Praktik Pembagian Harta Warisan Masyarakat Di Kelurahan Macanang Kecamatan Tanete Riattang Barat. Jurnal Hukum Keluarga Islam, $1(1)$. 